\title{
EFFECT OF THERMAL PROCESSING METHODS ON THE PROXIMATE COMPOSITION, GROSS ENERGY, MINERALS AND RICIN CONTENT OF UNDECORTICATED CASTOR OIL SEED (RICINUS COMMUNIS)
}

\author{
E. E. NSA AND S. N. UKACHUKWU \\ (Received 15 July , 2009; Revision Accepted 12 November, 2009)
}

\begin{abstract}
The nutritive value of raw and thermal processed castor oil seed (Ricinus communis) was investigated using the following parameters; proximate composition, gross energy, mineral constituents and ricin content. Three thermal processing methods; toasting, boiling and soaking-and-boiling were used in the processing of the seed as a way of improving its nutritive value. The three methods achieved a drastic reduction in the ricin levels. Toasting, boiling and soaking-and-boiling reduced ricin level by $93.05 \%, 94.84 \%$ and $97.76 \%$ respectively. Apart from Iron and potassium the thermal processing methods significantly $(P<0.05)$ reduced the levels of all other measured constituents. Toasting, as a processing method, achieved a higher proximate components (apart from crude protein and crude fibre), gross energy, mineral and ricin content than boiling and soaking-and-boiling methods. However, the higher level of ricin retained and the lower level of crude protein of toasted seed, make it the least preferred among the thermal processing methods, while soaking-and boiling that gave the least level of ricin and high level of crude protein is to be more preferred.
\end{abstract}

KEYWORD: Ricinus communis, toasting, boiling and soaking-and-boiling.

\section{INTRODUCTION.}

The shortage of good quality feeds needed to sustain livestock/poultry production has been a major challenge to the industry in the developing countries. This has been blamed on the rising needs of man for the same feedstuffs for his food and industrial raw material use (Duruna et al. 2006). There is therefore need to source for alternative inexpensive and readily available ingredients that have comparative nutritive value. However, most of these non-conventional feedstuffs are saddled with some toxic substances and anti-nutritional factors that have been found to be labile to thermal treatments. The thermal treatment, most time, are aimed at eliminating or reducing the level of toxic and inhibitory substances, which make them unsafe for consumption, elimination of these anti- nutritional factors makes nutrient contained in the ingredients to be biologically available to the animals that consume them and the toxic ingredients safe for consumption (Ukachukwu and Obioha, 1997).

Castor oil seed (Ricinus communis) has been identified as an underutilized feed resource of livestock. It grows naturally over a wide variety of soil (Weedfact, 2003), and yield under favorable condition about 20-25 bushels $(363-454 \mathrm{~kg}$ ) of seeds (beans) per acre (Hill, 1982).

The crude protein level of castor seed ranks with those of groundnut (38.88\%), Mucuna cochinchinesis(30.60\%), bambara groundnut(28.59\%), Jack beans $(29.43 \%)$ but lower than that of soybean $(43.00 \%)$, the richest among the vegetable protein sources (Ene-Obong and Carnovale, 1992; Apata and Olughobo, 1994; Ukachukwu and Obioha, 1997). Harnold (2002) reported the raw seed to have $21-48 \%$ crude protein, the wide range was said to be dependent on the extent of decortications, and has ideal amino acid profile with moderately high cystine, methionine, tryptophan and isoleucine. However, the raw unprocessed seed is poisonous to people, animals and insects. One of the main toxic proteins is ricin which is believed to have cytostatic and then cytotoxic effects in the cells, its action is said to be on the ribosomes of cytoplasm and mitochondria (Lugmer, 1952). The toxin in castor oil cake is said to exhibit antitrypsin action as found in some legumes like soybean (Clarke and Clarke, 1975). Castor oil bean also has agglutinating property due to agglutinin another toxin found in castor oil meal (Merex, 1997). However, poisoning by ingestion of the castor bean is due to ricin not agglutinin, because agglutinin does not affect red blood cells unless given intravenously (Vietta and Thorpe, 1991).

As a result of the presence of ricin, there are limited studies on the feeding value of the meal. However several findings on the detoxification of the bean through various processing methods have been documented. Thermal treatments have proven a successful method of detoxifying the seeds (Okorie et al. 1985).

The aim of this study is therefore to investigate the extent to which different thermal processing methods can affect the nutritive value of castor oil seed using proximate composition, gross energy, mineral composition and ricin content as indices of assessment.

E. E. Nsa, Department of Animal Science, University of Calabar, Calabar, Nigeria

S. N. Ukachukwu, College of Animal Science and Animal Health, Federal University of Agriculture, Umudike, Abia State, Nigeria. 
MATERIALS AND METHODS

Castor oil seeds were gotten from Ogoja in Cross River State, Nigeria. Sample seed A was the raw seed sample while samples $B, C$ and $D$. were castor seeds subjected to three thermal processing methods; boiling, toasting and boiling with pre-soaking respectively.

\section{Boiling:}

Water was brought to boil at $1000 \mathrm{C}$ before pouring in the seeds and then allowed to boil for 30 minutes before being drained off using local basket. The samples were then dried, milled, sieved with $1.55 \mathrm{~mm}$ mesh-sieved and bottled in an air tight container.

\section{Boiling with pre-soaking}

Seeds were soaked for 24 hours before being poured into boiling water and allowed to boil for 30 minutes. Decanting of water, drying, milling, sieving and bottling all followed the same procedure as in boiling above.

\section{Toasting}

Seeds were toasted in a drum of sand that was made to attain a temperature of about $140 \mathrm{oC}$. Turning of the sand was carried out for 3minutes after every 2 minutes and at 30 minutes of toasting, content were poured into a locally made bamboo basket, sand sieve out and seed cooled for subsequent grinding and storing in an air tight container.

\section{Proximate composition, Energy, Mineral and Ricin determination.}

The proximate contents of both the raw and the different processed seeds were determined by the method of AOAC (1990). Adiabatic oxygen bomb calorimetry technique was used to determine the gross energy. The mineral elements determined were Potassium, Calcium, Magnesium, Phosphorus and Iron. Determination of Potassium was by flame photometry method (AOAC, 1990). Calcium, Magnesium and Iron were determined by atomic absorption spectrophometry (AOAC, 1990), while determination of Phosphorus was by the Ammonium molybdate method as modified by Fiske and Subbarow (1990) using hydroquinone as a reducing agent. The protein-ricin component was extracted from castor oil meal with methanol under reflux for 24 hours in accordance with the method of Mise et al. (1971) as amended by Okorie et al (1985). The methanolic extracts were partitioned with petroleum ether to remove the liquid phase. The defatted extracts were then tested for presence of protein using a ninhydrin solution. Gel filtration, a molecular chromatography was employed to separate the components using a phosphate buffer of $\mathrm{pH} 7.4$. The ricin was carefully removed using a pipette and its level measured.

\section{RESULTS AND DISCUSSION}

The processing methods showed some significant $(\mathrm{P}<0.05)$ effect in all the parameters considered except for potassium and iron content of the seed.

The toasted seed had the least $\mathrm{CP}$ value, while boiled and soaked-and-boiled seeds had statistically similar values that were significantly lower $(P<0.05)$ than the raw seed. The toasted, boiled and soaked-andboiled seeds had $20.78 \%, 7.04 \%$ and $11.84 \%$ decrease in CP respectively over the raw seeds (Table 2). The observed decrease in crude protein in boiled and soaked-and-boiled seeds could be attributed to solubilisation and leaching of some nitrogenous substances in water. Iyaji and Egbarevba (1998) and Akinmutimi (2007) reported decrease in crude protein during boiling of Mucuna utilis. Also Okorie et al (1985) also recorded decrease in the crude protein value of castor oil seed during boiling. They all attributed it to loss of soluble nitrogenous parts of the seeds into the cooking water. Boiling and soaking-and-boiling appears to improve protein value more than toasting. The low crude protein level of toasted seed could be due to the loss of some testa in the sand. Castor seed testa is found to contain about $7.5 \%$ crude protein (Nsa, 2008). The range of $\mathrm{CP}$ obtained (24.66-27.43\%) for the thermal treatments compared favorable with other legumes grains such as cooked lima bean, boiled jacked bean and boiled sword bean having crude protein content of $21.50 \%, 25.88 \%$ and $25.83 \%$ respectively (Akinmutimi, 2004b), an indication that the thermal treatments still make castor oil seed a potential source of vegetable protein for both livestock and poultry birds.

The thermal treatments significantly $(P<0.05)$ affected the crude fibre level of the seed. Toasted seed had the least CF level while boiled and soaked-andboiled seeds had similar $(P>0.05)$ values that were lower $(P<0.05)$ than the raw seed. This decrease in $C F$ could be due to the loss of testa in the sand and water. The level of CF in the thermal treated seeds is still on the high side if is to be used as feedstuff for monogastric animals. High fibre has been shown to contribute to reduced feed intake in chickens (Abdelsamie et al, 1983: Ani and Okorie, 2004).

The ash content of $\mathrm{R}$. communis dropped by $10.70 \%, 10.34 \%$ and $19.07 \%$ for toasted, boiled and soaked-and-boiled seeds respectively less than the raw seed. There were significant $(P<0.05)$ differences in ash content of the different prepared seed meal. Soakedand-boiled seed meal had the least Ash value. The observed low level of ash of boiled and soaked-boiled seed meal could be due to the dehulling and solubilisation of some minerals which must have predisposed the seeds to some kind of leaching of some mineral elements. The lower level recorded for soakedand-boiled seed when compared to boiled seed is an indication that soaking encouraged more dehulling and subsequent leashing of minerals..

The ether extract varied from $18.73 \%$ in boiledand-cooked seeds, to $21.12 \%$ in raw seed. Boiled seeds and soaked-and-boiled seeds values showed nonsignificant effect but were lower $(P<0.05)$ than the ether extract value of toasted seed. This seemingly decrease in ether extract due to thermal treatments is in line with the report by Udedibie and Mba (1994); Udedibie et al. (1996); Ukachukwu and Obioha (1997) for pigeon pea and jack beans respectively, who both attributed it to the 
dehulling effect, due to thermal treatment which must have predisposed the seeds to some kind of solubilization and leaching out of its fats. The observed high level of ether extract in toasted seed (of only $7.39 \%$ less than the raw seed) when compared to boiled and soaked-and-boiled seeds could be due to a lower level of fat volatilization. This agrees with findings by Ukachukwu and Obioha (1997) who found little or no noticeable change in volatilization of fat in a toasted $M$. cochinchinensis seed.

The NFE differed significantly $(P<0.05)$ among the thermal treatments with toasted seed having a significantly $(P<0.05)$ higher value than both soakedand-boiled and boiled seeds in that order. The toasted, boiled and soaked-and-boiled seeds had $31.18 \%$, $16.863 \%$ and $24.30 \%$ respectively, which is an improvement in NFE over the raw seed (Table2). The reason for the general increase in the NFE could be due to lower levels of other proximate components; ash, crude protein, crude fibre and ether extract, which will increase the level of NFE which is usually obtained by subtraction of these components from $100 \%$. The high value of NFE implies that besides its potentials as a protein concentrate for livestock/poultry feeds, it could also double as energy source.

Apart from toasted seed, both boiled and soaked-and-boiled seeds had a significantly $(P<0.05)$ lower level of gross energy. Boiling and soaking-boiling reduced the GE of the seed by $6.56 \%$ and $6.96 \%$ respectively, over that of raw seed. The same reason as that given for ether extract could be attributed to GE, since oil has direct effect on GE.

The mineral composition of the seed meals were significantly $(\mathrm{P}<0.05)$ affected by treatments. Calcium was the most abundant of the elements considered with values ranging from $0.74 \mathrm{mg} / \mathrm{g}$ in soaked-and-boiled seeds to $0.84 \mathrm{mg} / \mathrm{g}$ in raw seeds, about $11.90 \%$ dropped in Calcium level. Except for Iron and Potassium content which were not affected by treatment methods all other mineral elements were significantly $(P<0.05)$ reduced by thermal treatments. The most affected was soaked-and-boiled seeds. This shows that there was much leaching of these minerals in soaked-and-boiled seeds than other thermal treatment methods.

The three thermal processing methods resulted to varying degrees of detoxify-cation of ricin in the raw seed (Table 1\&2). Soaking-and-boiling resulted in the highest detoxify-cation of ricin, followed by boiling and toasting in that order. The detoxify-cation represented $93.05 \%, 94.84 \%$ and $97.74 \%$ reduction of ricin brought about by the toasting, boiling and soaking-and-boiling, respectively. The higher degrees of detoxify-cation of ricin in soaked-and-boiled seed could have been due to the pre-soaking that softened the seed coat which then exposes some of the ricin to leaching. The general drastic reduction of ricin due to thermal processing methods is in agreement with reports by Okorie et al. (1985) where seeds of Ricinus communis toasted at $140^{\circ} \mathrm{C}$ for 20 minutes or more completely eliminated ricin component of castor oil seed. Also Kakade (1980) in his findings reported that most anti-nutritional factors in oil seeds are reduced and eliminated by proper application of heat.

In conclusion the three thermal processing methods seem to be very effective in improving the nutritive value of castor oil seed. However, according to their level of crude protein, carbohydrate and ricin content, soaking-and-boiling is most preferred while toasting is least preferred.

Table 1- Proximate composition, Gross energy, Mineral and Ricin content of Ricinus communis seeds.

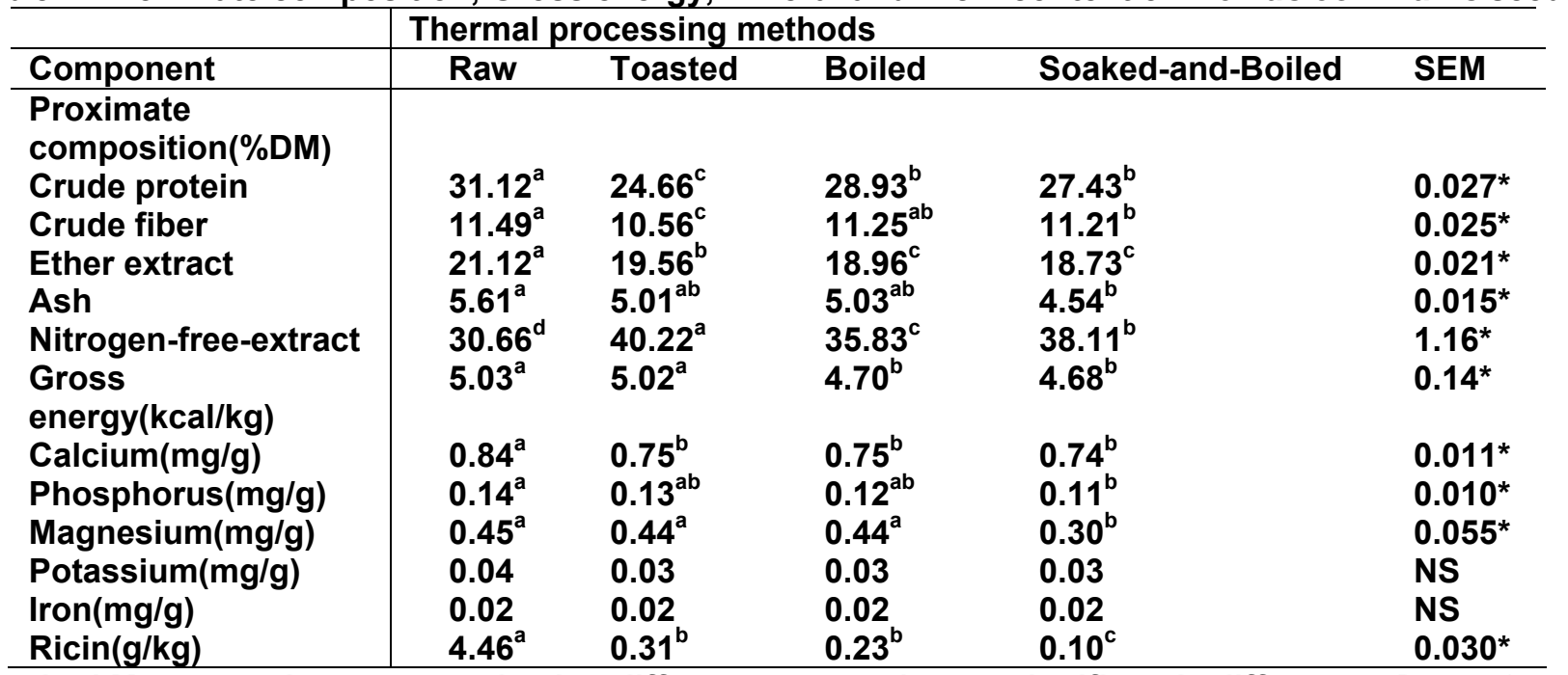

abcd Means on the same row having different superscript are significantly different at $P<0.05^{*}$ 
Table 2- Percentage changes in proximate components, mineral constituents and ricin content of Ricinus communis as influence by thermal processing methods.

\begin{tabular}{l|llll}
\hline \multicolumn{5}{|c}{ Thermal processing methods } \\
\hline Component & Raw & Toasted & Boiled & Soaked-and-Boiled \\
\hline Proximate & & & & \\
component & & & & \\
Crude protein & 0.00 & -20.76 & -7.04 & -11.86 \\
Crude fibre & 0.00 & -8.09 & -2.09 & -2.44 \\
Ether extract & 0.00 & -.7 .39 & -10.23 & -11.34 \\
Ash & 0.00 & -.10 .70 & -10.34 & -19.07 \\
NFE & 0.00 & 31.18 & 16.86 & 24.30 \\
Gross & 0.00 & -0.20 & -6.56 & -6.96 \\
energy(kcal/g) & & & & \\
Calcium(mg/g) & 0.00 & -10.71 & -10.71 & -11.90 \\
Phosphorus(mg/g) & 0.00 & -.7 .14 & -14.29 & -21.43 \\
Magnesium(mg/g) & 0.00 & -.2 .22 & -2.22 & -33.33 \\
Potassium(mg/g) & 0.00 & -25.00 & -25.00 & -25.00 \\
Iron(mg/g) & 0.00 & 0.00 & 0.00 & 0.00 \\
Ricin(g/kg) & 0.00 & -93.05 & -94.84 & -97.76 \\
\hline
\end{tabular}

\section{REFERENCES}

Abdelsamie, R. E., Ranaweera, N. P. and Nano, W. E., 1983. The influence of fibre content and physical texture on the performance of broilers in the tropics. Brit Poult. Sci. 24:383-390.

Akinmutimi, A. H., 2004b. Effect of cooking periods on the nutrient composition of Mucuna utilis seeds. Nigeria Poultry Science Journal 2 and 3:45-51.

Akinmutimi, A. H., 2007. Effect of cooking periods on the nutrient composition of velvet beans (Mucuna pruriens). Proc. $32^{\text {nd }}$ annual conference of Nig. Soc. For Anim. Prod. (NSAP), University of Calabar, Calabar.

AOAC., 1990. Association of Official Analytical Chemists. Official methods of analysis. Red Washington D. C

Ani, A. O. and Okorie, A. U., 2002. Response of broiler finishers to graded levels of dietary castor oil bean (Ricinus communis) meal supplemented with L-lysine. Proc. $27^{\text {th }}$ Ann. Conf. Nig. Soc. For Anim. Prod. (NSAP), March, 17-21. Fed. Univ. of Tech. Akure, Nig. 141-143.

Apata, D. F. and Olughobo, A. D., 1994. Biochemical evaluation of some Nigerian legume seeds. Food Chemistry. 49:33-38.

Clarke, R. C. and Clarke, M., 1975. Toxins in castor oil seed. Reginal vertinary toxicology. $1^{\text {st }}$ edition Bailliers Trindall, London.

Durunna, C. S., Udedibie, A. B. I. and Anyanwu, G. A., 2006. Combination of maize/sorghum based dried brewers'grain, cocoyam corn and cassava tuber meals as substitutes for maize in the diets of laying hens. J. Agric. Biotech. Environment, 1:17
Ene-Obong, H. N. and Carnovale, E., 1992. Nigerian soup condiments: traditional processing and potential as dietary fibre source. Foodchem. 43:29-34.

Fiske, C. H. and Subbarow, Y., 1925. The colorimetric determination of Phosphorus. J. Biol. Chem. 66, 375-377.

Hanold, L. M., 2002. Castor bean. An oil crop for mechanical production. Agrom. 10:258-266

Hill, N. G., 1982. Dominance and epitastisis as components of heterosis. Z. Tierz Zunchtung 99:161-168.

ljayi, E. A. and Egharevba, J. I., 1998. Biochemical and evaluation of seeds of an underutilized legume(Mucuna utilis). Nig. J. Anim. Prod. 25(1):40-45.

Kakade, N. L., 1980. Determination of trypsin inhibitor activity. A collaborative analysis of improved procedure. Cereal chem.. 52:376.

Lugmer, A. A., 1952. Ricin the toxic protein of castor oil plant (Ricinus communis) structure and properties. Vet. Rec. 64:567.

Merex, I., 1997. An encyclopedia chemical drugs and biology. Merex and co. Inc. Railway, New Jersey, London.

Mise, T., Funatsen, I. M.and Isihnie, F. M., 1971. Isolation and separation of ricin from castor bean. Agric. And Chem. 41(18)2041-2042.

Nsa, E. E., 2008. Chemical and biological assay of castor oil meal (Ricinus communis) as an alternative nutrient source in pullet birds diets. PhD thesis. Department of Animal Nutrition and Forage, Micheal Okpara, University of Agriculture, Umudike, Abia State, Nigeria. 
Okorie, A. U., Anugwa, F. O. I., Anamelechi, G. C. and Nwaiwu, I., 1985. Heat treated castor oil bean (Ricinus communis). A potential livestock protein supplement in tropics. Nutrition Reports International. 32:659-666.

Udedibie, A. B. I. and Mba, U. N., 1994. Studies on the use of pigeon pea (Cajanus cajan) as feed ingredient in layers' diets. J. Appl. Chem. and Agric. Res. 1(1)1-5.

Udedibie, A. B. I., Esonu, B. O., Unachukwu, C. and Iwuoha, N. C., 1996. Two stage cooking as a method of improving the nutritive value of jackbean
(Canavalia ensiformis) for broilers. Nig. J. Anim. Prod. 23(2) 107-110.

Ukachukwu, S. N. and Obioha, F. C., 1997. Improving the nutritive value of Mucuna cochinensis by thermal processing methods. J. Appl. Chem. And Agric. Res. 4:42-46.

Vietta, E. S. and Thorpe, P. E., 1991. Immunotoxins containing ricin or it,s $A$ chain. Seminar in cell biology. 2:47-58.

Weedfat, L., 2003. Influence of castor oil meal on intake of broiler birds. Sutherland Shire Council's Bushcare, Washington D. C. 